\title{
Land Use Cover changes in the western escarpment of Rift Valley in the Gamo Zone, Southern Ethiopia
}

\author{
Temesgen Dingamo ${ }^{1}$, Serekebirhan Takele ${ }^{2}$, Sebsebe Demissew ${ }^{3}$ and Zerihun Woldu ${ }^{3}$ \\ ${ }^{1} \mathrm{PhD}$ candidate, Biodiversity Conservation and Research Center, College of Natural Science, Arba Minch \\ University, Ethiopia, P. O. Box 21, Ethiopia. Tel: +251966894271, E-mail: temesgendingamo@yahoo.com \\ ${ }^{3}$ Professor, Department of Plant Biology and Biodiversity Management, Addis Ababa University, Addis
}

Ababa, Ethiopia. Tel: +251911247616, E-mail: sebseb.demissew@gmail.com

${ }^{3}$ Professor, Department of Plant Biology and Biodiversity Management, Addis Ababa University, Addis

Ababa, Ethiopia. Tel: +251911407255, E-mail: zerihun.woldu@aau.edu.et

${ }^{2}$ Associate Professor, Department of Biology, College of Natural and Computational Sciences, Arba

Minch University, Arba Minch, Ethiopia. Tel: +251911744711, E-mail: sereke100@yahoo.com

*, Corresponding author, e-mail: temesgendingamo@yahoo.com, Tel: +251966894271, Fax: +251468810279

\section{Abstract}

LULC changes are caused by natural and human alterations of the landscape that could largely affect forest biodiversity and the environment. The aim of the study was to analyzed LULC change dynamics in the western escarpment of the rift valley of the Gamo Zone, Southern Ethiopia. Digital satellite images downloaded from USGS were analyzed using ERDAS Imagine (14) and Arc GIS 10.2 software and supervised image classification was used to generate LULC classification, accuracy assessment and Normalized Difference Vegetation Index (NDVI). Drivers of LULC change were identified and analyzed. Four land classes were identified such as forest, farmland, settlement and water-wetland. Settlement and farmlands have increased by $7.83 \%$ and $5.88 \%$, respectively. On the other hand, both forest and water bodies and wetland decreased by aerial coverage of $11.03 \%$ and $2.68 \%$, respectively. The overall accuracy of the study area was $92.86 \%, 94.22 \%$ and $94.3 \%$ with a kappa value of $0.902,0.92$ and 0.922 , respectively. NDVI values ranged between -0.42 to 0.73. Agricultural expansion (31.4\%), expansion of settlement (25.7\%) and Fuelwood collection and Charcoal production (22.9\%) were the main driving forces that jeopardize forest biodiversity of the study area. Integrated land use and policy to protect biodiversity loss, forest degradation and climate changes are deemed necessary.

Keywords: Landsat images, Land use/land cover, Change detection, Rift valley 


\section{INTRODUCTION}

Land use land cover change (LULCC) is a major issue of concern with regards to change in a global environment [1]; changes are so pervasive such that, when aggregated globally, they significantly affect key aspects of Earth System functioning[2,3]. This directly impacts biodiversity throughout the world [4]; contribute to local and regional climate change [5] as well as to global climate warming [6]; are the primary sources of soil degradation [7]; and, by altering ecosystem services, affect the ability of biological systems supporting human needs [8]. Such changes also determine, in part, the vulnerability of places and people to climatic, economic, or socio-political perturbations [9].

The land is the major natural resource in which economic, social, infrastructure and other human activities are undertaken [10]. Thus, changes in land use that has occurred at all times in the past, currently on-going, and is likely to continue in the future $[11,12]$. These changes have beneficial or detrimental impacts, the latter being the principal causes of global concern as they impact human well-being and safety [13; 3]. LULC changes are widespread, accelerating, and the trade-offs offset human livelihood [14]. The rapid growth and expansion of urban centers, population pressure, scarcity of land, changing technologies are among the many drivers of LULC in the world today [15].

[16] Stated that land cover change occurs through conversion and intensification by human intervention, altering the balance of an ecosystem, generating a response expressed as system changes. For centuries, humans have been altering the earth's surface to produce food through agricultural activities [17]. In the past few decades, the conversion of grasslands, woodlands, and forests into croplands and pastures has risen dramatically, especially in developing countries where a large proportion of the human population depends on natural resources for their livelihoods [17, 18, and 19]. The increasing demand for land and related resources often results in changes in land use/cover [16] and it has local, national, regional and global causes and implications [20].

In Africa, forests cover about (21.4\%) of the land area which corresponds to 674 million hectares and in Eastern Africa alone approximately 13\% of the land area is under forests and 
woodlands [21]. [22] noted that close to $40 \%$ of Ethiopia might have been covered by high forests and that about $16 \%$ of the land area was covered by high forests in the early $1950 \mathrm{~s}$ (EFAP 1994). In the early 1980s the high forest cover of Ethiopia declined to $3.6 \%$ and further declined to $2.7 \%$ in 1989 [23]. The recent estimate of the land cover of Ethiopia that could qualify as 'forests' which includes high forests, woodlands, plantations, and bamboo forests adds up to $15 \%$ [24].

Land cover change occurs naturally in a progressive manner but, could sometimes be rapid and abrupt due to anthropogenic activities [25]. Vegetation cover change is a process in which the level of diversity and the density of individual species that makes up the natural vegetation structure are altered as a result of natural and human-induced pressure [26;27]. Vegetation change mapping and monitoring are useful when changes in the vegetation attributes of interest result in detectable changes in image radiance, emittance, or microwave backscatter values [28]. Many research results in Ethiopia indicate some of the critical threats to forests that need to be seriously addressed. One of these is land use/ cover changes [29, 30 and 31]. There is a dearth of LULC change detection studies in the study area and hence, the present study aims to evaluate and analyze LULC change detection at the southwest escarpment of the rift valley of Gamo Zone, Southern Ethiopia.

\section{MATERIALS and METHODS}

\subsection{Description of the Study Area}

The study was carried out in the western escarpment of the rift valley of the Gamo Zone, Southern Ethiopia. Gamo Zone is bordered by Dirashe Special Woreda in the South, Gofa Zone in the NW, Dawro and Wolayita Zones in the north, Lake Abaya and Chamo in the NE, South Omo in the South and Amaro Special Woreda in the SE (Figure 1). Araba Minch town is the administrative center of Gamo Zone. 


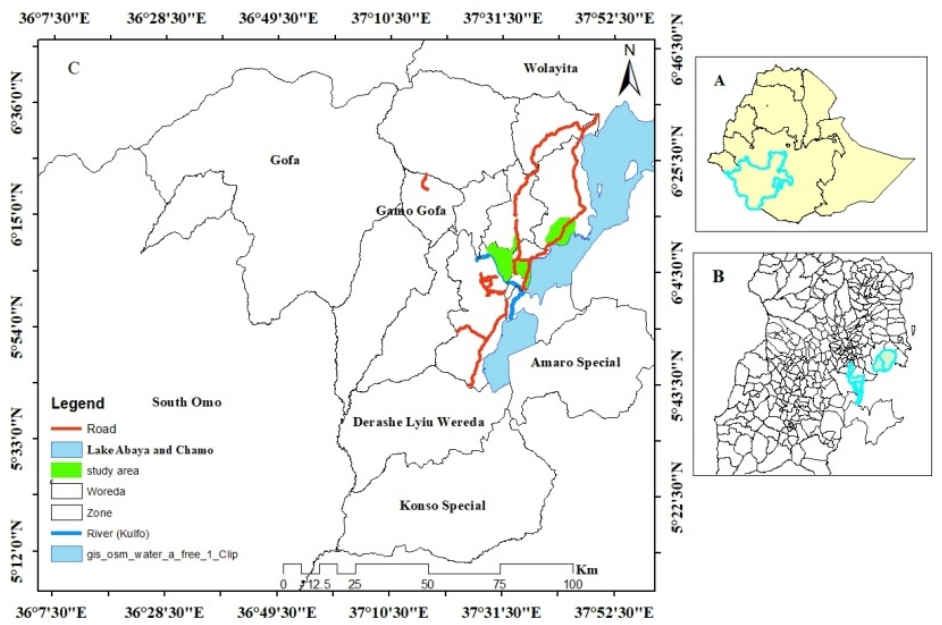

Figure 1: Location map for the study area $(\mathrm{A}=$ Ethio-Region, $\mathrm{B}=$ Gamo Zone, $\mathrm{C}=$ Study area (surrounded Zone, Lake Abaya and Chamo, Rivers and Roads all weathered)) (Source: Arc GIS 10.2 and CSA)

The study area consists of plains and hillsides of the Gamo mountain ridge between $6^{\circ} 05^{\prime} \mathrm{N}$ to $6^{\circ} 12^{\prime} \mathrm{N}$ and $37^{\circ} 33^{\prime} \mathrm{E}$ to $37^{\circ} 39^{\prime} \mathrm{E}$. The elevation of the area ranging from $1168 \mathrm{~m}$ to $2535 \mathrm{~m}$ a.s.1 and the slope of the forest ranges between 0 to 32 degrees (Figure 2). The total population in the study area is estimated to be 195,858 in the 2019 projection population (CSA, 2019) (Table 1). Drainage in the study area is seasonal and many streams from the mountain chains merge to form the Kulfo and Hara rivers which eventually join the western escarpment of the Central Rift Valley to Lakes (Chamo and Abaya).

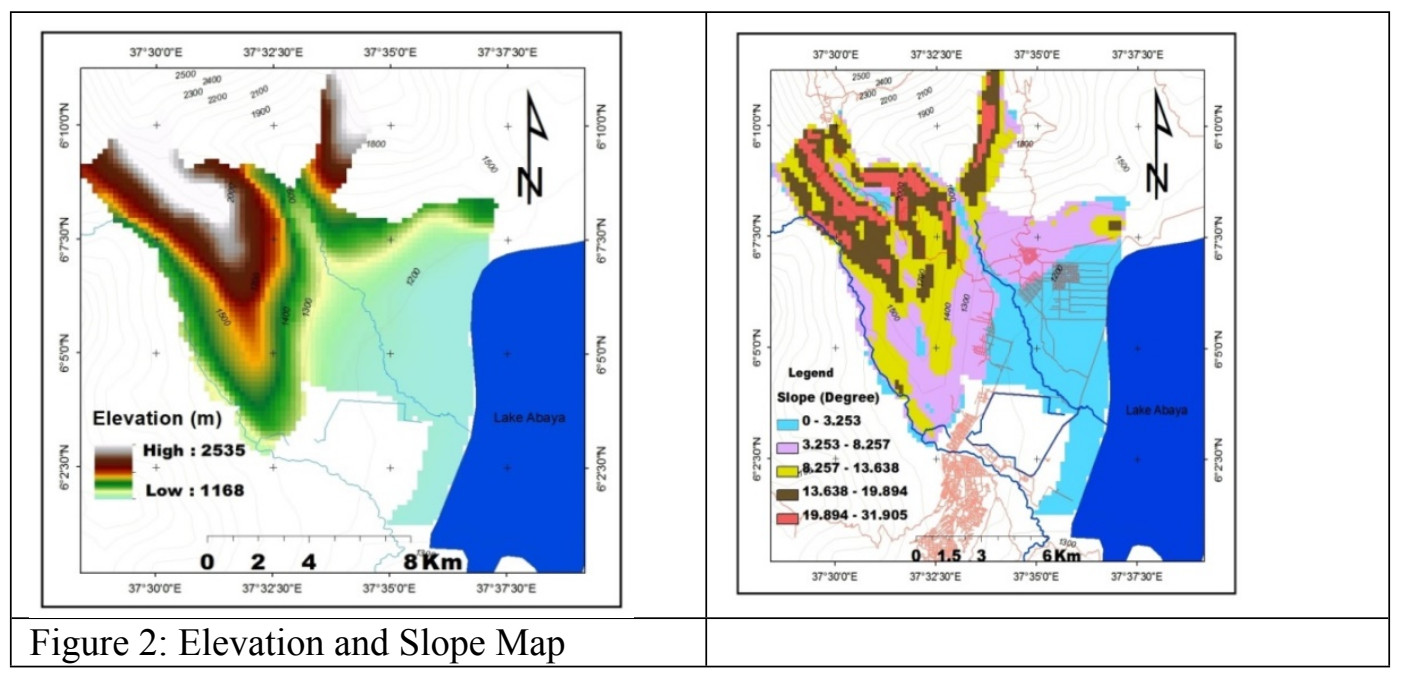

\section{Population}

The total population of the study area was increased in the three successive periods (1999, 2009 and 2019) (Table 1) (CSA, 2019). 
Table 1: Total Population of the study area from 1999-2019 (CSA, 2019)

\begin{tabular}{|c|c|c|c|c|}
\hline \multirow[b]{2}{*}{ Year } & \multicolumn{3}{|c|}{ Arba Minch Zuria } & \\
\hline & $\bar{M}$ & $\mathrm{~F}$ & Total & \\
\hline 1999 & 58,062 & 55,468 & 113,530 & \\
\hline 2009 & 82,751 & 82,929 & 165,680 & \\
\hline 2019 & 97,905 & 97,953 & 195,858 & projection population \\
\hline
\end{tabular}

104

\section{Geology and soil}

106

107

The geology of the Rift-valley escarpment is mainly quaternary volcanic alluvial deposits and lacustrine clay. Forest and the state farm are composed of three main types: Fluvisols, Gleysols and Vertisols. Fluvisols consist of soil materials developed in alluvial deposits and flood plains [32]. The Rift valley floor near Lake Abaya and Chamo is filled with alluvial sediments. The bedrock in the region consists of basalt, trachyte, rhyolite, and ignimbrite and the western edges of Lake Abaya are covered by approximately 1 to $2-\mathrm{km}$ wide plain of lacustrine and swamp deposits [33]. The topsoil textural classes of major soils in its spatial distribution are mainly dominated by clay loam, light clay, loam sand and sandy clay loam based on USDA classification.

\section{Vegetation Cover}

According to [34], the study area is characterized by complex vegetation types such as Combretum-Terminalia woodland vegetation, Acacia-Commiphora woodland vegetation and Dry evergreen Montana forest. The most common tree species in the study area are Terminalia brownii, Combretum molle, Ziziphus mucronata, Pappea capensis, Cadaba farinosa, Vachellia and Senegalia Acacia species, Balanites aegyptiaca, Commiphora abyssinica, Rhus natalensis, Olea europaea, Psydrax schimperiana, Acokanthera schimperi, etc.

\section{Climate}

The study area has a bimodal rainfall type. Maximum and minimum mean annual rainfall during 1999-2019 was $1141.1 \mathrm{~mm}$ and $491.8 \mathrm{~mm}$, respectively (Figure 3). The maximum and minimum mean annual temperature was $33.6^{\circ} \mathrm{C}$ and $15^{\circ} \mathrm{C}$, respectively (Figure 3) [35]. 


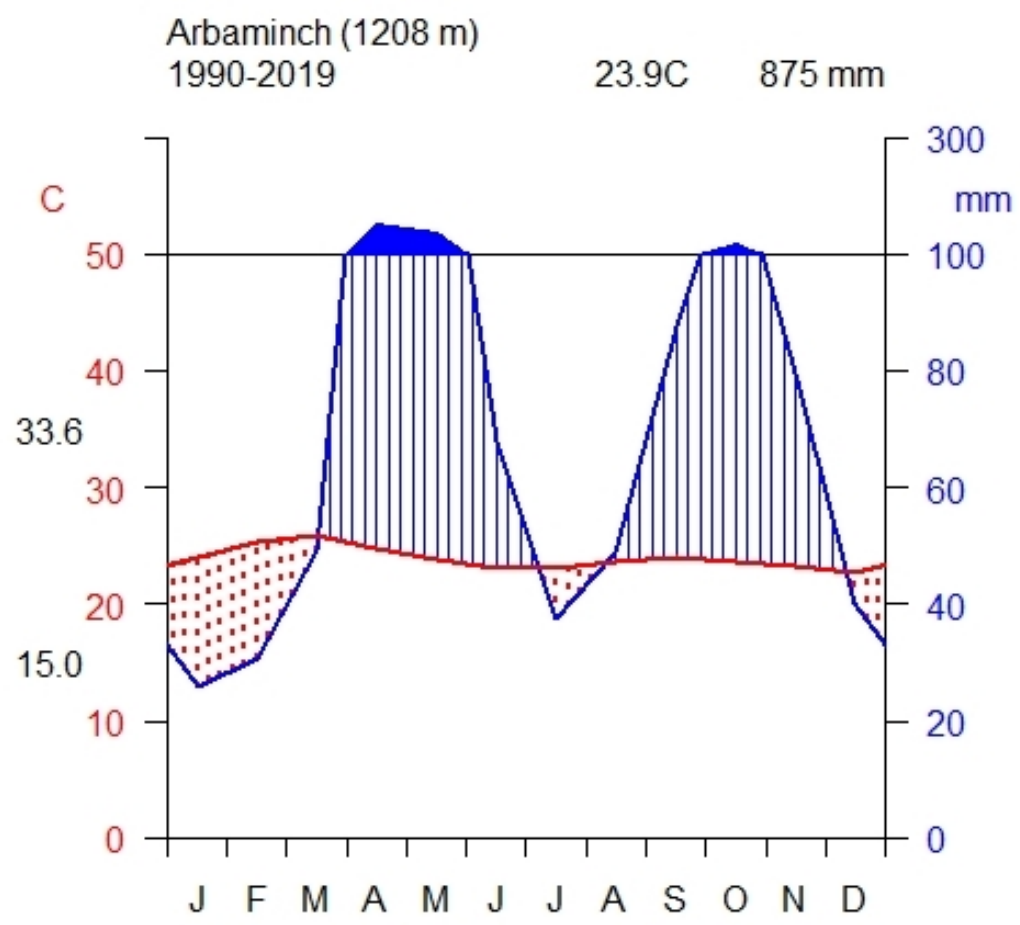

Figure 3: Annual Max. and Min. temp.in ${ }^{0} \mathbf{C}$ and rainfall in mm (1990-2019)

\subsection{Data types and sources}

Primary and secondary data were used: Ground control points (GCP) for ground truth were collected as primary data using handheld GPS. Secondary data include Landsat Thematic Mapper (TM) for the year 1999, ETM+ for the year 2009 and Landsat 8 Operational Land Imager (OLI) images for the year 2019 acquired from United States Geological Survey online imagery portals (http:// glovis.usgs.gov). Other Geo-spatial data include Shapefiles and topographic maps collected from the Central Statistical Agency (CSA) and Ethiopian Mapping Agency (EMA) for extraction and delineation of area of interest (Table 2).

Table 2: Remote sensing data of the study

\begin{tabular}{|l|l|r|r|rr|l|l|}
\hline $\begin{array}{l}\text { Acquisition } \\
\text { data }\end{array}$ & Sensors & \multicolumn{1}{l|}{$\begin{array}{l}\text { Path and } \\
\text { Row }\end{array}$} & $\begin{array}{l}\text { Spatial } \\
\text { Resolution } \\
\text { bands }\end{array}$ & $\begin{array}{l}\text { Number of } \\
\text { Format }\end{array}$ & Source \\
\hline $01 / 05 / 1999$ & TM & 169,56 & $30 \mathrm{~m}$ & 7 & TIFF & USGS \\
\hline $01 / 05 / 2009$ & ETM $^{+}$ & 169,56 & $30 \mathrm{~m}$ & 8 & TIFF & USGS \\
\hline $01 / 05 / 2019$ & OLI & 169,56 & $30 \mathrm{~m}$ & 11 & TIFF & USGS \\
\hline
\end{tabular}




\subsection{Land-use change assessment (1999-2019)}

142 Digital satellite images were processed classified and analyzed using ERDAS Imagine (14).

143 Computations of the area and changes in land use categories were made using Arc GIS 10.2 software analytical tools. Pre-processing of satellite images was done to create a more faithful representation of the original scene. An intensive pre-processing such as geo-referencing, layer-stacking, resolution merge, and sub sets were carried out to Ortho-rectify the satellite images into UTM coordinates (WGS, 1984 ) and to remove disturbances such as haze, noise, steep slope effect, and radiometric variation between acquisition dates. A stacked satellite image of the study area was extracted by clipping the Area of Interest (AOI) layer of the Gamo shapefile in ERDAS 14 software.

The satellite image was classified using the supervised image classification technique and employed pixel-based supervised image classifications with the maximum likelihood classification algorithm [36] to produce LULC maps of the study area. Appropriate band combinations were obtained and the signatures were used for the supervised classification. Land cover change detection for the study area was monitored at three intervals: 1999_2009, 2009_2019 and 1999_2019. Supervised classification into four land classes were categories and distinguished into farmlands, forest lands, settlement, water bodies and wetlands (Table $3)$.

Table 3: Characteristics of land cover classes

\begin{tabular}{|l|l|}
\hline Class name & Description \\
\hline Farmlands & Areas used for crop cultivation (Maze, teff, Banana, Mango, etc.). \\
\hline $\begin{array}{l}\text { Dense forest } \\
\text { scattered forest } \\
\text { and woodland }\end{array}$ & $\begin{array}{l}\text { This habitat is dominated by trees characterized by a multi-storeyed } \\
\text { nature with the crown cover of almost 10-50\% }\end{array}$ \\
\hline Settlement & Different settlements (villages) associated with building \\
\hline Water_wetland & $\begin{array}{l}\text { areas where water cover and may support both aquatic and wetland } \\
\text { species }\end{array}$ \\
\hline
\end{tabular}

\subsection{Accuracy analysis}

162 Since image classification without accuracy assessment is incomplete [37], accuracy assessment for the images was carried out. The accuracy of the classification was assessed using producers, users and overall methods of accuracy assessment. The overall accuracy, as well as Kappa statics, was calculated based on the GCP collected from the identified land-use types. Kappa statics was calculated by the following equation:- 
Kappa $=\frac{\text { (observed Agreement }- \text { Expected Agreement) }}{1-\text { Expected Agreement }}$

\subsection{Land use land covers change detection}

The LULC maps of three years showing period's with a range of ten years in between (1999, 2009 and 2019) were generated from the satellite imageries using supervised maximum likelihood classification. To analyze the land cover structural changes in the study area the table showing the area in hectares and percentage changes between the periods 1999_2009, 2009_2019 and 1999-2019 were measured for each LULC type. Change detection was calculated by:-

$\mathrm{R}=Q 2-Q 1 / t$

Where, $\mathrm{R}=$ Rate of Change, $\mathrm{Q}_{2}=$ Recent year forest cover in ha

$\mathrm{Q}_{1}=$ Initial Year forest cover in ha and

$\mathrm{t}=$ Interval year between Initial year and Recent year

\subsection{Vegetation index}

Normalized Difference Vegetation Index (NDVI) is one of the indicators commonly used to detect the vegetation cover of the earth's surface i.e. spectral change detection method. NDVI values were calculated on composite image and used band 3 (Red) and 4 (Near Infrared) for Landsat 7, and band 4 (Red) come with band 5 (Near Infrared) for Landsat 8. NDVI approaching calculation of greenness degree of image correlates with vegetation crown density. NDVI correlates with chlorophyll content and its value is between -1 to 1 . NDVI is calculated as:

Where: NDVI $=$ Normalized Difference Vegetation Index, NIR $=$ Near Infra-Red Band $\mathrm{R}=$ Red Band

\subsection{Drivers of LULC changes}

LULC changes are influenced by a number of driving factors. In the study area, human 
197 (FDG) and key informant interview (KII). KII and FGD were selected based on the recommendation of local community leaders and agriculture extension workers. The participants included elders (male and female), agriculture extension workers and youth jobless. The informants were asked for their consent to participate in the discussion were then given clear information about LULC changes in the study area. Data were analyzed using IBM SPSS version 20.

\section{RESULTS AND DISCUSSION}

\subsection{Land use land covers classification}

205 The Four land classes identified in the study include forest, farmland, settlement and water bodies and water-wetlands. The land use land cover categories in Figure 4 show that forest

207 land class has progressively decreased while farmlands and settlement increased from 208 19992019.
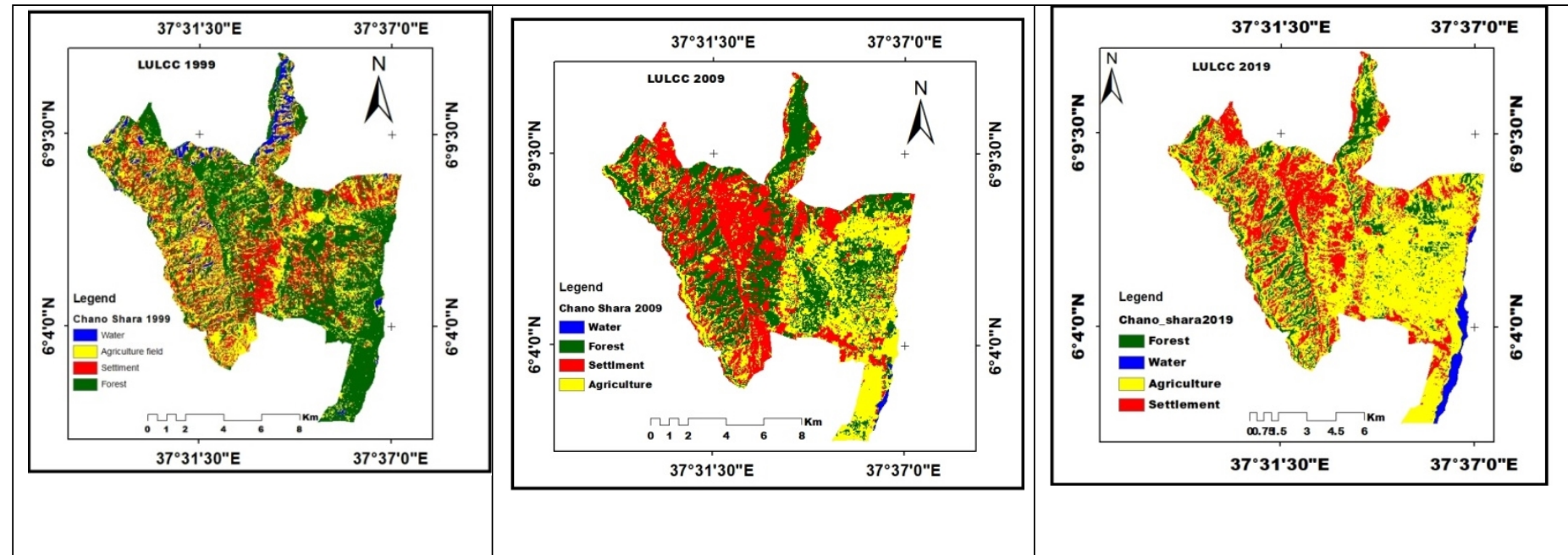

Figure 4: Land use land cover change from 1999_2019

210 Similar results were reported by [38; 39; and 40] showing that farmlands in the Rift Valley of

211 Ethiopia have expended as a result of population pressure.[41] has shown that more than 4/5

212 of the total terrestrial productive land in the Ethiopian Central Rift Valley was lost to

213 agriculture. Conversions to other land use types have been observed and the image

214 classification shows a clear conversion of land covers into farmland and settlement (Table 4).

\subsection{Land use land covers change}

216 Results revealed that the extent of land cover changes from forest to farmland in the last three

217 decades was rapid. The decline of water bodies and wetlands was not as dramatic as the loss

218 of forests (Table 4). The conversion of farmlands to settlements was equally high. Similar 
219

results were reported by [42 and 43] in the Finchaa Catchment, North-western Ethiopia and Abijata Shalla National Park, respectively. This is due to small-scale irrigation by pumping water from the lakes and rivers for income generation through the production of fruit and vegetables. [44] also showed that urban settlements and farmland expansion gained the most in the area compared to other LULC types, while forest areas exhibited a decreasing trend. Demand for food and grazing land for the growing population appears to be the driving factors.

Table 4: Land use land covers change (1999_2019)

\begin{tabular}{|l|r|r|r|r|r|r|}
\hline Area & \multicolumn{1}{|l|}{$\begin{array}{l}\text { Area (ha) } \\
\left(1999 \_2009\right)\end{array}$} & \multicolumn{1}{l}{$\begin{array}{l}\text { Area (ha) } \\
(\text { 2009_2019) }\end{array}$} & $\begin{array}{l}\text { Area (ha) } \\
(1999- \\
2019)\end{array}$ & \multicolumn{1}{l|}{} \\
\hline Forest - Agriculture & 1416.156 & 11.4 & 2671.36 & 21.51 & 1878.42 & 15.13 \\
\hline Forest - Settlement & 500.144 & 4.03 & 284.27 & 2.29 & 376.529 & 3.03 \\
\hline Agriculture - Forest & 155.922 & 1.26 & 105.00 & 0.85 & 50.315 & 0.41 \\
\hline Agriculture-Settlement & 142.651 & 1.15 & 408.7 & 3.29 & 376.529 & 3.03 \\
\hline Agriculture - Water & 235.9683 & 1.9 & 166.1 & 1.34 & 232.268 & 1.87 \\
\hline Water - Agriculture & 384.342 & 3.09 & 401.85 & 3.24 & 277.00 & 2.23 \\
\hline
\end{tabular}

\subsection{Land use land covers change detection}

LULC change detection was showing that the areal coverage of settlement and farmlands increased. On the other hand, both forest and water_wetland were decreased by an aerial coverage (Table 5). This was due to the conversion of forest and water_wetland, to settlement and farmlands increased and also Lake Abaya might be fluctuated increased and or decreased its volume, but mostly at the expense of forest lands (Table 5). [44] shown that urban settlements and farmland expansion gained the most in the area compared to other LULC 
types, while forest areas exhibited a decreasing trend (Figure 5). Demand for food and grazing land for the growing population seems the probable driving force, among others.

Table 5: Land use land covers change detection from 1999 to 2019

\begin{tabular}{|c|c|c|c|c|c|c|}
\hline \multirow[t]{3}{*}{ Land class } & \multicolumn{6}{|c|}{ Rate change $(\mathrm{r}=\mathrm{Q} 2-\mathrm{Q} 1 / \mathrm{t})$} \\
\hline & \multicolumn{2}{|c|}{ 1999_2009 } & \multicolumn{2}{|c|}{ 2009_2019 } & \multicolumn{2}{|c|}{ 1999_2019 } \\
\hline & ha & $\%$ & ha & $\%$ & ha & $\%$ \\
\hline Settlement & 574.17 & 4.6 & 398.45 & 3.2 & 972.63 & 7.83 \\
\hline Agriculture & 628.62 & 5.06 & 101.1 & 0.81 & 729.72 & 5.88 \\
\hline Forest & -199.95 & -1.61 & -1169.79 & -9.42 & -1369.74 & -11.03 \\
\hline Water & -1002.83 & -8.08 & 670.23 & 5.4 & -332.6 & -2.68 \\
\hline
\end{tabular}

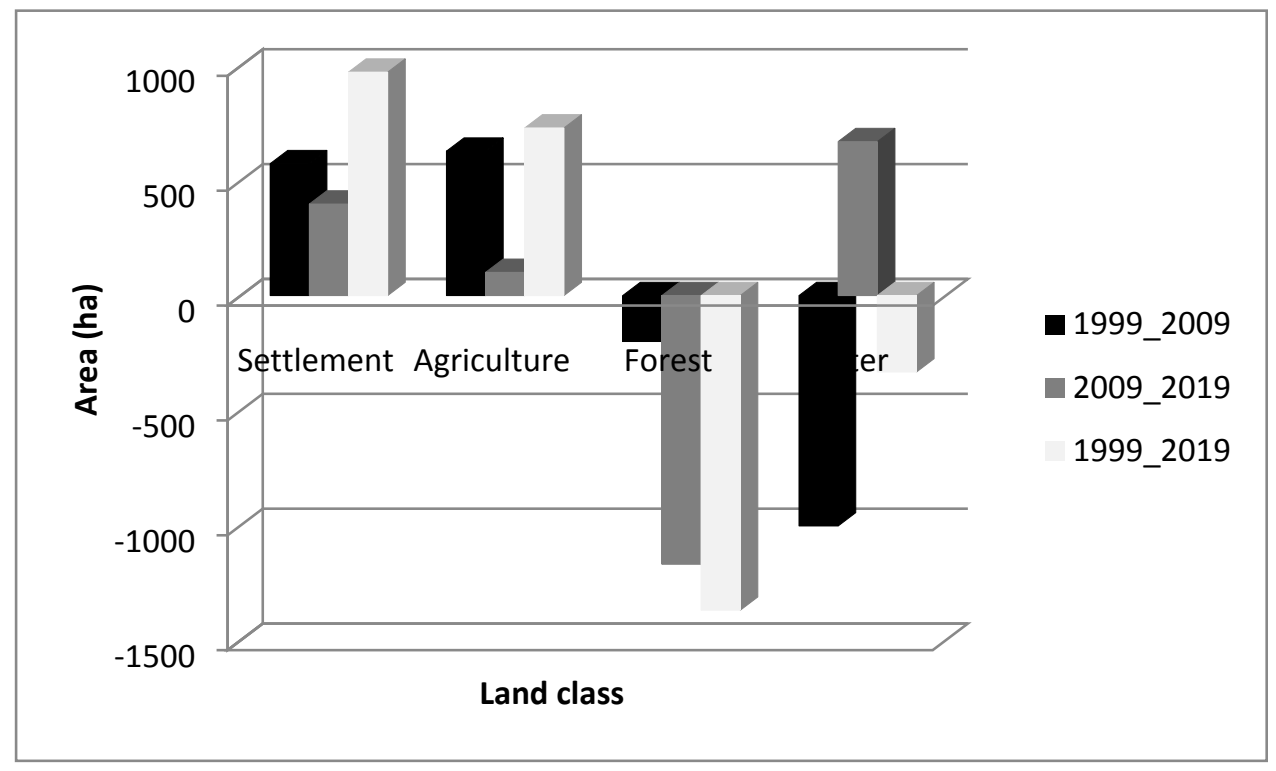

Figure 5: Change detection of the study area

\subsection{Overall accuracy assessment (1999, 2009 and 2019)}

248 The accuracy of image classification was checked with an accuracy matrix using 140, 173 and 158 randomly selected control points, respectively. The accuracy assessment was performed using land-use maps, ground truth points and Google Earth. Three periods (1999, 2009 and 2019) land use classification have shown, user's accuracy and producer's accuracy are greater than $85 \%$, as well the overall accuracy of $92.86 \%, 94.22 \%$ and $94.3 \%$ ( Table 7,8 and 9), respectively (Table 6, 7 and 8). These values indicate the LAND SAT images and the methodologies used were so accurate. The Kappa coefficient was also calculated, with a value of $\mathrm{K}=0.9$, which indicates that the classification is almost perfect since it is greater than 0.8. [45] argued that overall accuracy values greater than 0.8 indicate in the Landsat and the methodologies used to have high accuracy. 
Table 6: Overall accuracy of the study area (1999)

\begin{tabular}{|l|r|r|r|r|r|r|}
\hline & \multicolumn{6}{|l|}{ Ground truth } \\
\hline Land class & Settlement & Agriculture & Forest & Water & $\begin{array}{l}\text { Row } \\
\text { Total }\end{array}$ & $\begin{array}{l}\text { User's } \\
\text { Accuracy }\end{array}$ \\
\hline Settlement & 50 & 2 & 1 & 0 & 53 & $94.34 \%$ \\
\hline Agriculture & 0 & 29 & 0 & 1 & 30 & $96.67 \%$ \\
\hline Forest & 2 & 2 & 26 & 0 & 30 & $86.67 \%$ \\
\hline Water & 0 & 1 & 1 & 25 & 27 & $92.6 \%$ \\
\hline $\begin{array}{l}\text { Column } \\
\text { Total }\end{array}$ & 52 & 34 & 28 & 26 & 140 & \\
\hline $\begin{array}{l}\text { Producers } \\
\text { Accuracy }\end{array}$ & $96.15 \%$ & $85.3 \%$ & $82.86 \%$ & $96.15 \%$ & & $92.86 \%$ \\
\hline
\end{tabular}

259

260 Overall Classification Accuracy $=\underline{92.86 \%}$

261 KAPPA $\left(\mathrm{K}^{\wedge}\right)$ STATISTICS

262 Overall Kappa Statistics $=\underline{0.902}$

263 Table 7: Overall accuracy 0f the study area (2009)

\begin{tabular}{|l|r|r|r|r|r|r|}
\hline & \multicolumn{7}{|l|}{ Ground truth } & Settlement & Agriculture & Forest & Water & $\begin{array}{l}\text { Row } \\
\text { Total }\end{array}$ & $\begin{array}{l}\text { User's } \\
\text { accuracy }\end{array}$ \\
\hline Settlement & 47 & 2 & 1 & 0 & 50 & $94 \%$ \\
\hline Agriculture & 1 & 60 & 2 & 0 & 63 & $95.25 \%$ \\
\hline Forest & 1 & 1 & 36 & 0 & 38 & $94.74 \%$ \\
\hline Water & 0 & 1 & 1 & 20 & 22 & $90.91 \%$ \\
\hline $\begin{array}{l}\text { Column } \\
\text { Total }\end{array}$ & 49 & 64 & 40 & 20 & 173 & \\
\hline $\begin{array}{l}\text { Producers } \\
\text { Accuracy }\end{array}$ & $95.92 \%$ & $93.75 \%$ & $90 \%$ & $100 \%$ & & $94.22 \%$ \\
\hline
\end{tabular}

Overall Classification Accuracy $=\underline{\mathbf{9 4 . 2 2 \%}}$

265 KAPPA $\left(\mathrm{K}^{\wedge}\right)$ STATISTICS

266 Overall Kappa Statistics $=\underline{\mathbf{0 . 9 2}}$

Table 8: Overall accuracy of the study area (2019)

\begin{tabular}{|c|c|c|c|c|c|c|}
\hline & \multicolumn{6}{|c|}{ Ground truth } \\
\hline Land class & Settlement & Agriculture & Forest & Water & $\begin{array}{l}\text { Row } \\
\text { Total }\end{array}$ & $\begin{array}{l}\text { User's } \\
\text { accuracy }\end{array}$ \\
\hline Settlement & 54 & 2 & 1 & 0 & 57 & $94.74 \%$ \\
\hline Agriculture & 1 & 40 & 1 & 0 & 42 & $95.25 \%$ \\
\hline
\end{tabular}




\begin{tabular}{|l|r|r|r|r|r|r|}
\hline Forest & 1 & 1 & 30 & 0 & 32 & $93.75 \%$ \\
\hline Water & 0 & 1 & 1 & 25 & 27 & $92.59 \%$ \\
\hline $\begin{array}{l}\text { Column } \\
\text { Total }\end{array}$ & 56 & 44 & 33 & 25 & 158 & \\
\hline $\begin{array}{l}\text { Producers } \\
\text { Accuracy }\end{array}$ & $96.43 \%$ & $90.91 \%$ & $90.91 \%$ & $100 \%$ & & $94.3 \%$ \\
\hline
\end{tabular}

KAPPA (K^) STATISTICS

Overall Kappa Statistics $=\underline{\mathbf{0 . 9 2 2}}$

\subsection{Normalized difference vegetation index (NDVI)}

The statistics and visual observation of the NDVI images over three successive periods (1999, 2009 and 2019) showed that major land cover changes have taken in the study area (Figure 7). The threshold value of NDVI was approximately 0.73 (Figure 6). The pixels having an NDVI value above the threshold were identified as vegetated areas, while low NDVI values represented non-vegetated areas. For non-vegetated areas, we found that the water bodies were represented by low NDVI values, ranging from -0.28 to -0.42 , while the pixels having NDVI values in the range of 0.51 to 0.73 were considered as vegetation cover areas (Table 9). NDVI analysis has proven that there had been changes in vegetation cover between 1999 and 2019 images and higher values were recorded in the period 1999 in the study area.

Table 9: NDVI result of the study area

\begin{tabular}{|c|c|c|c|}
\hline $\begin{array}{l}\text { Statistics } \\
\qquad N D V I=\frac{(N I R-R)}{N I R+R)}\end{array}$ & 1999 & 2009 & 2019 \\
\hline Low & -0.42 & -0.28 & -0.37 \\
\hline High & 0.73 & 0.64 & 0.51 \\
\hline Mean & 0.18 & 0.059 & -0.21 \\
\hline SD & 0.11 & 0.095 & 0.11 \\
\hline
\end{tabular}



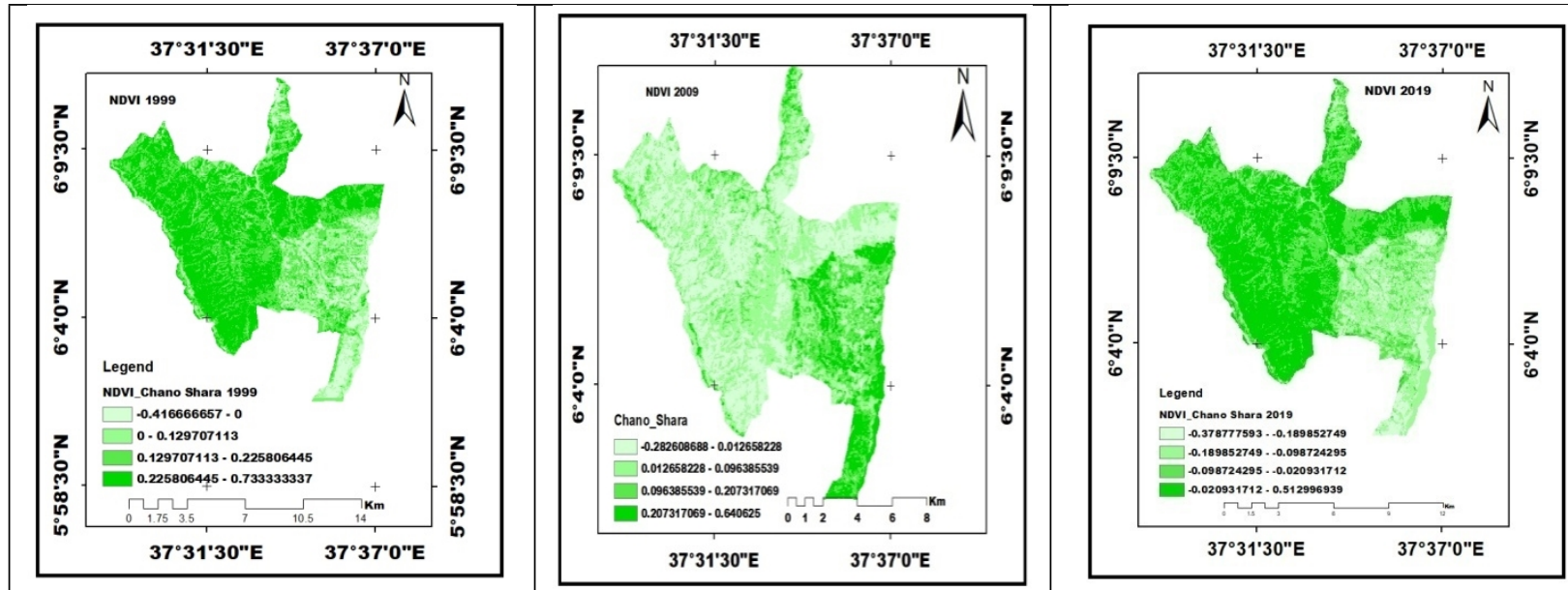

Figure 6: NDVI of the study area from 1999_2019

287

\subsection{Drivers of LULC changes}

289 The results of FGD and KII reveal the five major direct driving forces (Table 10). Among

290 these, agricultural expansion account, expansion of settlement and Fuelwood collection and

291 Charcoal production take large shares.

292 Table 10: Proximate causes of LULC changes

\begin{tabular}{|l|l|r|r|r|}
\hline № & \multicolumn{1}{|c|}{ Driver } & Frequency & \multicolumn{1}{l|}{ Rank } \\
\hline 1 & $\begin{array}{l}\text { Fuelwood collection, tree cutting and } \\
\text { Charcoal production }\end{array}$ & 8 & 22.9 & 3 \\
\hline 2 & Agricultural expansion & 11 & 31.4 & 1 \\
\hline 3 & Expansion of settlement & 9 & 25.7 & 2 \\
\hline 4 & Fire & 2 & 5.7 & 5 \\
\hline 5 & Overgrazing & 5 & 14.3 & 4 \\
\hline & Total & 35 & 100 & \\
\hline
\end{tabular}


293

294

295

296

297

298

299

300

301

302

303

304

305

306

307

308

309

310

311

312

313

314

315

316

317

318

319

320

321

The demographic data of the study area over the past three decades has revealed that population pressure ranked as the top cause of LULC changes (Table 11) [46]. The work of Lambin et al (2003) show that impact human population pressure is causing the accelerated conversion of natural habitats into agricultural and settlement areas to meet the mounting demand for food and housing. In Ethiopia, resettlement and villagization programs during the Military Government had made a significant contribution to the expansion of settlements and agriculture. Due to the low policy enforcing capacity of the then government landless farmers cleared forests and occupied as much land as possible to increase the chances of land ownership.

Table 11: Underlying causes of LULC changes

\begin{tabular}{|l|l|r|r|r|}
\hline No & Driver categories & Frequency & \multicolumn{1}{l|}{ R } & Rank \\
\hline 1 & Demographic & 13 & 37.1 & 1 \\
\hline 2 & Biophysical & 8 & 22.9 & 3 \\
\hline 3 & Economic & 10 & 28.6 & 2 \\
\hline 4 & Institution and policy & 4 & 11.4 & 4 \\
\hline & Total & 35 & 100 & \\
& & & & \\
\hline
\end{tabular}

\subsection{CONCLUSION and RECOMMENDATIONS}

There were four land classes in the study area including forest, farmland, settlement and water bodies and wetlands. The changes observed in 2009 and 2019 were more rapid than that in 1999 the expansion of small-scale irrigated farmlands for fruit and vegetable production. Field observations, KII and focus group discussant confirmed that the main cause of LULC changes in the study area was the expansion of farmland and settlement. On the other hand, demographic, economic and biophysical conditions were indirect driving forces of LULC changes.

Linking participatory forest management with an institution and strong monitoring policies, green legacy and creating awareness to local people is hopped to improve the current status forest biodiversity and environment of the study area. Furthermore, the land use policy and environmental rehabilitation policies of the country need to be revised to include biodiversity hotspots and sequestration of carbon for carbon trading. The environmental trade-offs of fruit and vegetable productions that fetch good economic income must be mitigated through payment for ecosystem services that can be channeled for payment to the workforce involved in green legacy and environmental rehabilitation. Furthermore, promoting none agricultural economy to the jobless youths and creating forest reserved areas with a buffer zone of the study area. 


\section{ACKNOWLEDGEMENT}

First of all, I would like to express my special thanks to almighty God who helped me in all my success. I am also very grateful to my supervisors Sebsebe Demissew, Zerihun Woldu and Serekebirhan Takele for their consistent and stimulating advice, valuable suggestions, constructive criticism, reading of the manuscript without his sincere collaborations the work would not have been completed. Moreover, I thank Arba Minch University for provided financial help throughout my research work and next, my gratitude goes to Biodiversity Conservation and Research Centre, School of Graduated studies and Biology Department for all support.

\section{REFERENCES}

1. Qian J, Zhou Q, Hou Q (2007). Comparison of pixel-based and object-oriented classification methods for extracting built-up areas in the arid zone. In ISPRS workshop on updating Geo-spatial databases with imagery \& the 5th ISPRS workshop on DMGISs. National GeomaticsCenter of China sponsored, pp. 163-171

2. Lewis S (2006). Tropical forests and the changing earth system. Philosophical Transactions of the Royal Society.Biological Sciences 361(1465):195-210

3. Zhao S, Peng C, Jiang H, Tian D, Lei X, Zhou X (2006). Land use change in Asia and the Dires Tewabe and Temesgen Fentahun (2020). Assessing land use and land cover change detection using remote sensing in the Lake Tana Basin, Northwest Ethiopia, Cogent Environmental Science, 6:1: 1-11

4. Osvaldo E. Sala, F. Stuart Chapin, Juan J. Armesto, Eric Berlow, Janine Bloomfield, Rodolfo Dirzo, Elisabeth Huber-Sanwald, Laura F. Huenneke, Robert B. Jackson, Ann Kinzig, Rik Leemans, David M. Lodge, Harold A. Mooney, Martín Oesterheld, N. LeRoy Poff, Martin T.Sykes, Brian H. Walker, Marilyn Walker and Diana H. Wall, New Series, Vol. 287, No. 5459 (Mar. 10, 2000), pp. 1770-1774

5. Chase, T.N., Pielke, R.A., Kittel, T.G.F., Nemani, R.R., Running, S.W., (1999). Simulated impacts of historical land cover changes on global climate in northern winter. Climate Dynamics 16, 93-105

6. Houghton RA, Hackler JL, Lawrence KT. (1999). The US carbon budget: contribution from land-use change. Science 285:574- 78

7. Tolba, M.K., El-Kholy, O.A. (Eds.), (1992). The World Environment 1972-1992:Two Decades of Challenge. Chapman \& Hall, London. 
8. Vitousek, P.M., Mooney, H.A., Lubchenco, J., Melillo, J.M., (1997). Human domination of earth's ecosystems. Science 277, 494-499

9. Kasperson, J. X. and R. E. Kasperson: (2001). 'International Workshop on Vulnerability and Global Environmental Change'.SEI Risk and Vulnerability Programme Report 2001-01, Stockholm Environment Institute, Stockholm, Sweden

10.Bashir MAA, (2012). The Impact of Land-Use Change on the Livelihoods of Rural Communities: A case-Study in Edd Al-Furssan Locality, South Darfur State, Sudan. Doctoral Dissertation, Technical University of Dresden pp:1-162

11.Lambin, E. F., Geist, H. J., \& Lepers, E. (2003). Dynamics of land-use and land-cover change in tropical regions. Annual Review of Environment and Resources, 28, 205-241

12.Moser, Susanne C., (1996). A partial instructional module on global and regional land use/cover change: assessing the data and searching for general relationships. GeoJournal, 39(3), pp. 241- 283.

13.Lewis S (2006). Tropical forests and the changing earth system. Philosophical Transactions of the Royal Society.Biological Sciences 361(1465):195-210

14.Agarwal C, Green GM, Grove JM, Evans TP, Schweik CM (2002). A review and assessment of land-use change models: dynamics of space, time, and human choice (Vol. 297). Newton Square, PA: US Department of Agriculture, Forest Service, Northeastern Research Station

15.Barros JX (2004). Urban growth in Latin American cities-Exploring urban dynamics through agent-based simulation (Doctoral dissertation, University of London).

16.Assefa B (2012). Land use /land cover change and its effect on Existing forest condition, the case of Shakiso Natural forest, southeast Ethiopia. Hawassa University, Wondo Genet College of forestry and natural resources, Wondo Genet, Ethiopia.

17.FAO (Food and Agriculture Organization of the United Nations) (2005). State of World's Forests. Food and Agriculture Organization of the United Nations, Rome 18.FAO (2010).Global forest resource assessment. In: FAO Forestry paper 163, Main Report, Rome, Italy

19.FAO.Global Forest Resources Assessment (2015). Desk Reference; Food and Agriculture Organisation of the United Nations: Rome, Italy, 2015; Available online: http://www.fao.org/3/a-i4808e.pdf (accessed on 21 September 2016)

20.Olsonm, J.M., Misana, S., Campbell, D.J., Mbonile, M. and Mugisha, S. (2004). Land Use Change, Impacts and Dynamics (LUCID). Project Working Paper Number 48, International Livestock Research Institute, Nairobi 
21.Naemi N, Gunlycke G, Anja A, Tuomaala T (2011). Geo-biosphere science Centre: Physical geography and ecosystems analysis. PhdHesis, Lund University, Lund, Sweden

22.EFAP (1994). The challenge for development: Final draft consultant report. Ministry of natural resources development and environmental protection, Addis Ababa, Ethiopia, Vol: 2

23.FAO- Food and Agriculture Organisation (2001). World Wide Agroclimatic Data Base.CD-ROM FAOClim 2. Rome, Italy

24.FAO. (2016). Forestry contribution to national economy and trade in Ethiopia, Kenya and Uganda. By Kilawe, E. and Habimana, D . UN: FAO.

25.Jensen JR (2005). Introductory Digital Image Processing: A Remote Sensing Perspective. New Jersy: Pearson Education, Inc

26.Belaynesh Z (2002). Perceptions of Forest Resource Changes in and around Wondo Genet Catchment and It's near Future Impacts. M.Sc. Thesis, Wondo Genet College of Forestry, Wondo Genet

27. Lu D, Mausel P, Brondizio E, Moran E (2004). Change detection techniques. Int. J. Remote Sensing 25(12): 2365-2407

28.Coppin P, Jonckheere I, Nackaerts K, Muys B, and Lambin E (2004). Digital change detection methods in ecosystem monitoring: A review. International Journal of Remote Sensing, 25:1565-1596

29.Efrem G, Sandewall M, Söderberg U, Campbell B (2009).Land-use and land-cover dynamics in the central rift valley of Ethiopia. Environmental Management 44 (4): 683694

30.Solomon B, Amsalu, A., Abebe, E. (2014). Land Use and Land Cover Changes in Awash National Park, Ethiopia: Impact of Decentralization on the Use and Management of Resources. Open Journal of Ecology, Vol, 4 PP. 950-960

31.Temesgen G, Amare B, Abraham M (2014). Evaluations of Land Use/Land Cover Changes and Land Degradation in Dera District, Ethiopia: GIS and Remote Sensing Based Analysis, International Journal of Scientific Research in Environmental Sciences, 2(6), pp. 199-208

32.Mateos A, Jim!eenez A, R!11osInsua S. (2003). Solving dominance and potential optimality in imprecisemulti-attribute additive problems. Reliability Engineering and System Safety 79: 253-262 
33.Chernet, T. (1982). Hydrogeologic map of the Lakes Region (with a memo). Ethiopian Institute of Geological Surveys, Addis Ababa, Ethiopia

34.FriisIb, Sebsebe D and VanBruegel P. (2010). Atlas of the Potential Vegetation of Ethiopia.The Royal Danish Academy of Science and letters, BiologiskeSkrifter. pp58 35.NMA (2019). National Metrological Agency of Ethiopia Addis Ababa, Ethiopia 36.Congalton, R., \& Green, K. (2009). Assessing the accuracy of remotely sensed data: Principles and practices (2nd ed.) CRC/Taylor \& Francis

37.Lillesand, T. M., R. W. Kiefer and J. W. Chipman (2003). Remote Sensing and Image Interpretation, Fifth Edition. New York, John Wiley \& Sons, 784 pp.

38.Kassa T (2009). Watershed Hydrological Responses to Changes in Land Use and Land Cover, and Management Practices at Hare Watershed, Ethiopia, Ph.D. Dissertation, Universität Siegen, Research Institute for Water and Environment

39.Ariti, A. T., van Vliet, J., \&Verburg, P. H. (2015). Land-use and land-cover changes in the central rift valley of Ethiopia: Assessment of perception and adaptation of stakeholders. Applied Geography, 65, 28-37

40.Daniel, A. M., Daniel, K. W., and Muluneh, W. (2012). Detection and analysis of landuse and land-cover changes in the Midwest escarpment of the Ethiopian Rift Valley. Journal of Land Use Science, 7, 239-260

41.Muzein, B. (2006). Remote Sensing \& GIS for Land Cover/ Land Use Change Detection and Analysis in the Semi-Natural Ecosystems and Agriculture Landscapes of the Central Ethiopian Rift Valley. PhD thesis, Technische Universität Dresden, Germanyecological consequences. Ecological Research 21:890-896

42.Wakjira T, Tamene A and Konrad M (2020). Drivers and Implications of Land Use/Land Cover Dynamics in Finchaa Catchment, Northwestern Ethiopia, MDPI, Basel, Switzerland, Land Open Access Journal, vol.9:2_20

43. Hamere Y, Ali M and Eyasu E (2017). Land Use/Land Cover Dynamics and Its Impact on Biodiversity Resources in the AbijataShalla National Park, Central Rift Valley Lakes Region, Ethiopia, Journal of Environment and Earth Science, Vol.7, No.11:33-42 44.Sisay N, Teshome S and Demel T (2016). Land Use and Land Cover Change in the Bale Mountain Eco-Region of Ethiopia during 1985 to 2015, journal of land, $5(41): 2 \_22$

45.Chrysoulakis N., Kamarianakis Y., Farsari Y., Diamandakis M., and Prastacos P. (2004). "Combining Satellite and Socioeconomic data for Land Use Models 
bioRxiv preprint doi: https://doi.org/10.1101/2021.09.08,459379; this version posted September 8,2021 . The copyright holder for this preprint (which was not certified by peer review) is the author/funder, who has granted bioRxiv a license to display the preprint in perpetuity. It is made available under aCC-BY 4.0 International license. on Remote Sensing for Developing Countries (in press) ecological implications in Wuhan, China. J Geogr Geol 3:104-118 
bioRxiv preprint doi: https://doi.org/10.1101/2021.09.08.459379; this version posted September 8, 2021. The copyright holder for this preprint (which was not certified by peer review) is the author/funder, who has granted bioRxiv a license to display the preprint in perpetuity. It is made available under aCC-BY 4.0 International license.

458

459

460

461

462

463

464 